\title{
Present Status of Ganges River Dolphins Platanista gangetica gangetica (Roxburgh, 1801) in the Turag River, Dhaka, Bangladesh
}

\author{
Mohammad Abdul Baki, ${ }^{1}$ Naser Ahmed Bhouiyan, ${ }^{1}$ Md. Saiful Islam, ${ }^{1}$ \\ Shayer Mahmood Ibney Alam, ${ }^{1}$ Shibananda Shil, ${ }^{2}$ and Md. Muzammel Hossain ${ }^{1}$ \\ ${ }^{1}$ Department of Zoology, Jagannath University, Dhaka 1100, Bangladesh \\ ${ }^{2}$ University Grants Commission of Bangladesh, Dhaka 1207, Bangladesh \\ Correspondence should be addressed to Md. Muzammel Hossain; muzammel3@gmail.com
}

Received 15 September 2016; Revised 9 April 2017; Accepted 18 May 2017; Published 14 June 2017

Academic Editor: Hynek Burda

Copyright ( $) 2017$ Mohammad Abdul Baki et al. This is an open access article distributed under the Creative Commons Attribution License, which permits unrestricted use, distribution, and reproduction in any medium, provided the original work is properly cited.

Freshwater ecosystem degradation in the Turag River basin is increasing due to rising human settlement, reduced water flow during the dry season, new large land development projects, and toxic emissions caused by brick kilns. The population of river dolphins was estimated through surveys carried out from December 2012 to November 2013. Surveys were conducted on a fortnightly basis. The dolphins were counted within an $18.4 \mathrm{~km}$ stretch (known to be the most polluted stretch) of the $75 \mathrm{~km}$ long river. A total of 62 dolphin sightings were recorded, both as individual sightings and as groups. The highest monthly count was in August. The besthigh-low estimates of 9-11-7 individuals were recorded in August 2013 in river ecology. Seasonal changes in spatial distribution were observed. The survey revealed that rising floodwater stimulated an increase in the dolphin population in the study area from July to October. The maximum encounter rate was also 0.49 sightings $\mathrm{km}^{-1}$ for the month of August. The sightings and encounter rates of dolphins were lower from December to July (dry and premonsoon period) likely due to reduced water flow and adverse water quality of this river.

\section{Introduction}

The Ganges river dolphin, Platanista gangetica gangetica (Roxburgh, 1801), also known as "shusuk" in Bangla, is a freshwater dolphin species distributed throughout the Ganges-Brahmaputra-Meghna river systems in India, Bangladesh, and Nepal $[1,2]$. Its geographical range has been reduced, and its abundance has declined in many areas where the animals still appear [3-5]. The International Union for Conservation of Nature (IUCN) revised the threatened status of the Ganges river dolphin from vulnerable [6] to endangered as per IUCN Global Red List guidelines [4]. At present, it is thought that there are about 3500 individuals of this species throughout its distribution range [7]. This species is placed on the First Schedule of Bangladesh Wildlife (Conservation \& Security) Act, 2012, and it is classified as endangered because of the numerous anthropogenic and natural constraints to its survival, for example, water pollution, boat traffic, and reduction of water flow during the dry season [8]; however, the population of river dolphins has declined rapidly in recent years with much of their habitat already degraded [4]. Freshwater ecosystems inhabit only $0.8 \%$ of the earth, but 100,000 species are estimated, which is about $6 \%$ of all described species [9]; unfortunately the river ecosystem is polluted due to human intervention.

The Turag River is tide-influenced and passes to the west-north and north of Dhaka City; its average width is $107 \mathrm{~m}$ with a total length of $75 \mathrm{~km}$ [10]. The river ecology is seriously impacted by heavy discharge of industrial effluents; indiscriminate dumping of household garbage and rubbish (including bottles, cans, clothing, and food packages), medical items, and commercial waste; petroleum hydrocarbon fuels; and untreated sewage wastes [11, 12]. Brick fields and land development projects have added pollution to the extent that the abundance and diversity of aquatic life have decreased alarmingly in the river $[11,12]$. 
In India, Choudhury [13] mentioned the distribution of this river dolphin species in both Brahmaputra and Barak river systems of Assam. In Nepal [14, 15], population status and distribution patterns of Ganges river dolphins in the major rivers, namely, Karnali, Narayani, Mahakali, and Kosi rivers, were investigated [16]. Anderson [17] recorded the upstream distribution of dolphins, not Jones [18], in the Meghna river system of the country. Other authors reported on the status of these dolphins in the Karnaphuli River, Halda River, Matamuhuri River, Bangkhali River, and Kaptai Lake of the country [19-22] but a comprehensive survey of the Turag River has not yet been conducted.

This paper discusses the status (sightings of individuals and groups, dolphin density, encounter rates, and ecology) and distribution of the Ganges river dolphins in the most polluted section of Turag River [11] and identifies areas where research and conservation activities are most needed. We emphasize collection of quantitative data for assessing the abundance of this river dolphin.

\section{Materials and Methods}

2.1. Study Period and Area. River dolphin survey was held in the Turag River from December 2012 to November 2013. The Turag River is about $75 \mathrm{~km}$ long, which was not feasible to cover in a day by the kind of motorboat used for survey. Therefore, the stretch of Amin Bazar bridge to Kamarpara bridge (approx. $18.4 \mathrm{~km}$ ) was surveyed by motorboat for river dolphin study. The survey team always started observations from Amin Bazar bridge $\left(23^{\circ} 47^{\prime} \mathrm{N} 90^{\circ} 20^{\prime} \mathrm{E}\right)$ and surveyed all the way to Kamarpara bridge $\left(23^{\circ} 52^{\prime} \mathrm{N} 90^{\circ} 24^{\prime} \mathrm{E}\right)$ in the Turag River (Figure 1). The Turag River is an upper tributary of Buriganga, a major river in Bangladesh. The river is so polluted that it has been declared as an "Ecologically Critical Area (ECA)" by the department of Environment, Government of Bangladesh [23, 24]. This section of the river is situated around Dhaka city and lots of industries are situated by this section of the river.

2.2. Data Collection and Analysis. This study was conducted on a fortnightly basis. Boat-based surveys were conducted twice per month, giving a total of 24 surveys during the study. Boats maintained a constant speed range of $7-10 \mathrm{~km} / \mathrm{h}$. Survey design followed previous studies conducted by different authors [15, 25-31]. The observation team mostly consisted of three researchers. An average of $18.4 \mathrm{~km}$ of the river was covered in each survey. River average width is about $0.1 \mathrm{~km}$. Sampling was undertaken in sighting condition in the river. The locations of dolphin sightings were recorded by a Garmin Map 72 GPS. We considered a single platform with 2 primary observers and 1 rear observer. Surveys began at 07:00 h and ended at 16:00 $\mathrm{h}$ during clear weather conditions in the river. Two primary members were positioned at the front of the boat and left and right of a data recorder and continually searched for dolphins using binoculars and occasionally with unaided eyes. Eye height was $1.5 \mathrm{~m}$ above the water surface. During survey period one interviewer visited river bank (other platform) and conducted a cross-check interview with boatmen and fishermen about sightings of dolphin. The question was "Did you see the susu or dolphin?"

Once a dolphin or a group was sighted, the number of individuals was recorded with a best-high-low estimate of group size. Encounter rates (sightings $\mathrm{km}^{-1}$ ), for each survey, were calculated by dividing the sightings (events) by the total distance surveyed. The direct count method was used to estimate the population $[15,32]$.

2.3. Hydrology of the River. The Bangladesh Water Development Board (BWDB) set up a water level monitoring station at Turag River to forecast the flood gauges in Dhaka city. This station was located at $23^{\circ} 78^{\prime} 33^{\prime \prime} \mathrm{N}$ and $90^{\circ} 34^{\prime} \mathrm{E}$ for daily monitoring of Turag River's water level, which included staff gages. Therefore, this study collected daily water depth data during the study period from the BWDB office (72 Green Road, Farmgate, Dhaka, Bangladesh).

\section{Results}

3.1. Sightings and Number. A total of 62 sightings of dolphins were recorded in the entire $18.4 \mathrm{~km}$ survey area of the river (Table 1). Of these sightings, 17 were groups (range of 23 individuals per group), while 45 sightings were single individuals (Table 1). Maximum numbers of dolphins were observed $(n=9)$ in August with best-high-low estimate of 911-7, followed by October with 8-10-7 individuals (Figure 3). Maximum number of sightings $(n=9)$ was observed in August and October, while the minimum $(n=3)$ was in December, January, and February. We identified three locations as dolphin hotspots (Tamanna Park, Birulia, and Rustampur) as the highest number of dolphins was sighted at those locations despite a high level of human disturbance.

3.2. Dolphin Distribution. Dolphins were observed at 10 locations in the study area (Table 1). Dolphins appeared at the following locations: Amin Bazar Bridge, Nober par, Tamanna Park South, Tamanna Park North, Birulia Landing Station, Birulia Bhanga bridge, Uttara 3rd phase, Rustampur, Ashulia Landing Station, and Kamarpara area of the river (Figure 1). Dolphins were observed at Rustampur, Tamanna Park South, and Birulia Landing Station consistently almost throughout the year (Table 1); at the other sites, dolphins were recorded from August to October 2013.

3.3. Dolphin Encounter Rates. We recorded that highest encounter rate of dolphins was 0.49 sightings $\mathrm{km}^{-1}$ in October 2013 and lowest encounter rate of dolphins was 0.16 sightings $\mathrm{km}^{-1}$ in December 2012 to February 2013, respectively, in the Turag river $(18.4 \mathrm{~km})$ (Figure 6). Water depth varied monthly in the Turag River during this study (Figure 2). Water depth began to increase in May due to premonsoon rain. This initial increase in discharge was followed by very sharp rise due to monsoon, usually occurring in June and July, leading to peak flood in August and September. The water depth normally decreases after these peaks from September onwards, reaching a minimum level in March. 


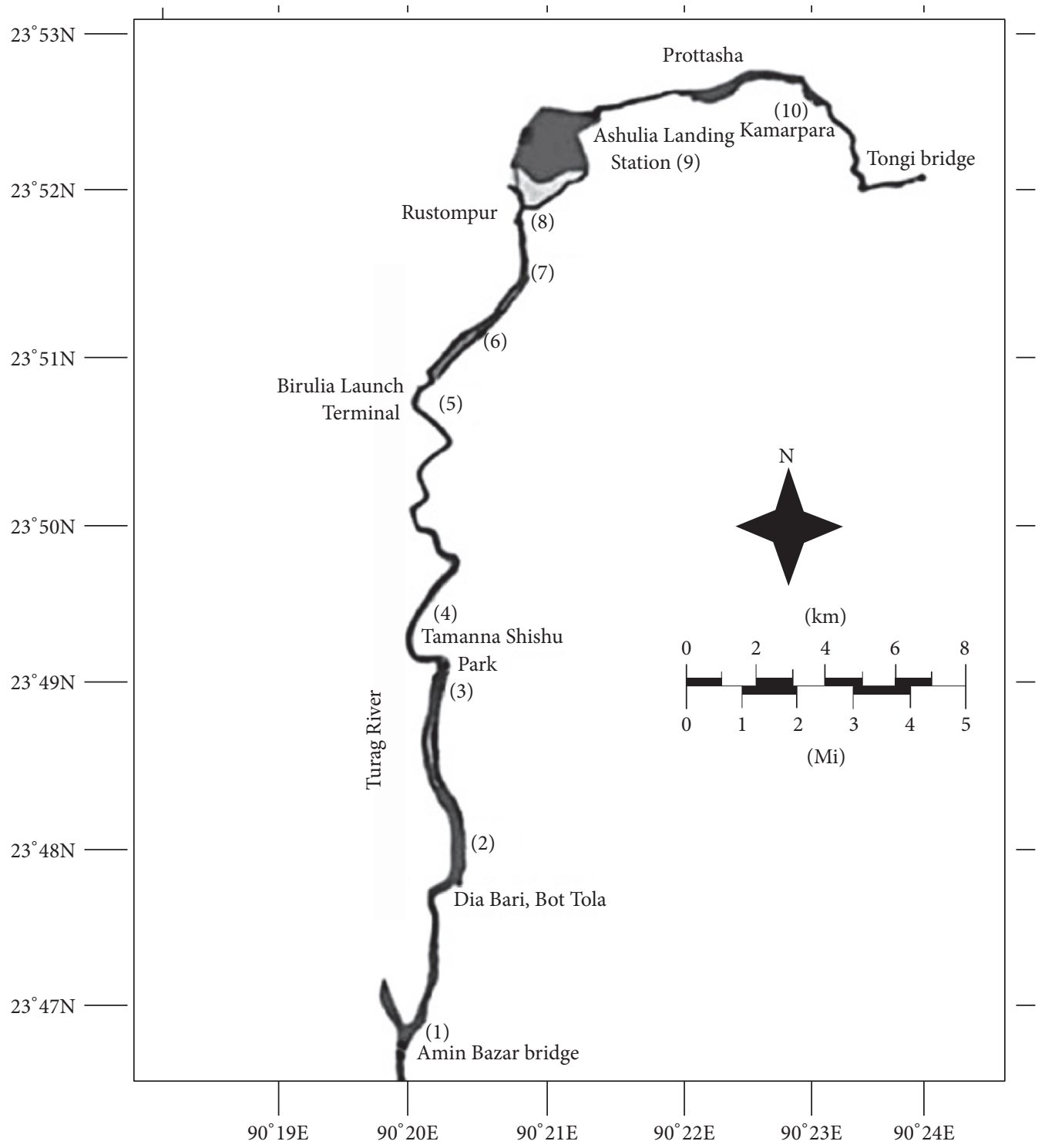

(1) Amin Bazar bridge
(2) Nober par
(3) Tamanna Park South
(4) Tamanna Park North
(5) Birulia Landing Station

(6) Birulia Bhanga bridge

(7) Uttara 3rd phase

(8) Rustampur

(9) Ashulia Landing Station

(10) Kamarpara

Figure 1: Map of the Turag River.

\section{Discussion}

Our survey indicates that the Amin Bazar and Birulia area is the most important stretch of the Turag River in terms of dolphin abundance. This study is an effort to make an informed assessment of river dolphin's status in specific areas in this river for the first time. Alam and Sarker [26] mentioned that the Ganges river dolphins are location-specific and they identified 15 locations in the Buriganga River, which is adjacent to the present study's site. However, we also found the dolphins in 10 different specific locations within the study area (Table 1). Seasonal changes in distribution were found: the maximum number of dolphin sightings was recorded in the wet season (August to November); dolphin sightings decreased from December to February because of the dry season. Lower counts in the dry season may be because pollution is concentrated and dolphins migrate to other areas [12]. Water pollution, reduced water flow, and boat traffic were observed to be the major threats of the river dolphins in the Turag River ecology. Interviewer also recorded answer 
TABLE 1: River dolphin appears at different geographical position on different time in the Turag River.

\begin{tabular}{|c|c|c|c|c|c|c|c|c|c|c|c|c|c|c|}
\hline Sl. number & Place & GPS coordinate & Dec & Jan & Feb & Mar & Apr & May & Jun & Jul & Aug & Sep & Oct & Nov \\
\hline (1) & Amin Bazar bridge & $23^{\circ} 47^{\prime} \mathrm{N}$ and $90^{\circ} 20^{\prime} \mathrm{E}$ & & & & & & & $\sqrt{ }$ & & $\sqrt{ }$ & & $\sqrt{ }$ & \\
\hline (2) & Nober par & $23^{\circ} 48^{\prime} \mathrm{N}$ and $90^{\circ} 20^{\prime} \mathrm{E}$ & & & & & & & & & & $\sqrt{ }$ & $\sqrt{ }$ & $\sqrt{ }$ \\
\hline (3) & Tamanna Park South & $23^{\circ} 49^{\prime} \mathrm{N}$ and $90^{\circ} 20^{\prime} \mathrm{E}$ & $\sqrt{ }$ & $\sqrt{ }$ & $\sqrt{ }$ & $\sqrt{ }$ & $\sqrt{ }$ & $\sqrt{ }$ & $\sqrt{ }$ & & $\sqrt{ }$ & $\sqrt{ }$ & $\sqrt{ }$ & \\
\hline (4) & Tamanna Park North & $23^{\circ} 49^{\prime} \mathrm{N}$ and $90^{\circ} 20^{\prime} \mathrm{E}$ & & & & & $\sqrt{ }$ & & & $\sqrt{ }$ & $\sqrt{ }$ & $\sqrt{ }$ & $\sqrt{ }$ & $\sqrt{ }$ \\
\hline (5) & Birulia Landing Station & $23^{\circ} 50^{\prime} \mathrm{N}$ and $90^{\circ} 20^{\prime} \mathrm{E}$ & $\sqrt{ }$ & $\sqrt{ }$ & $\sqrt{ }$ & $\sqrt{ }$ & $\sqrt{ }$ & $\sqrt{ }$ & $\sqrt{ }$ & $\sqrt{ }$ & $\sqrt{ }$ & $\sqrt{ }$ & & $\sqrt{ }$ \\
\hline (6) & Birulia Bhanga bridge & $23^{\circ} 51^{\prime} \mathrm{N}$ and $90^{\circ} 20^{\prime} \mathrm{E}$ & & & & $\sqrt{ }$ & & $\sqrt{ }$ & $\sqrt{ }$ & & $\sqrt{ }$ & $\sqrt{ }$ & $\sqrt{ }$ & $\sqrt{ }$ \\
\hline (7) & Uttara 3rd phase & $23^{\circ} 51^{\prime} \mathrm{N}$ and $90^{\circ} 21^{\prime} \mathrm{E}$ & & & & & & & & $\sqrt{ }$ & $\sqrt{ }$ & & $\sqrt{ }$ & $\sqrt{ }$ \\
\hline (8) & Rustampur & $23^{\circ} 52^{\prime} \mathrm{N}$ and $90^{\circ} 21^{\prime} \mathrm{E}$ & $\sqrt{ }$ & $\sqrt{ }$ & $\sqrt{ }$ & $\sqrt{ }$ & $\sqrt{ }$ & $\sqrt{ }$ & $\sqrt{ }$ & $\sqrt{ }$ & $\sqrt{ }$ & $\sqrt{ }$ & $\sqrt{ }$ & $\sqrt{ }$ \\
\hline (9) & Ashulia Landing Station & $23^{\circ} 53^{\prime} \mathrm{N}$ and $90^{\circ} 21^{\prime} \mathrm{E}$ & & & & & & & & & $\sqrt{ }$ & $\sqrt{ }$ & $\sqrt{ }$ & \\
\hline$(10)$ & Kamarpara & $23^{\circ} 52^{\prime} \mathrm{N}$ and $90^{\circ} 24^{\prime} \mathrm{E}$ & & & & & & & & & $\sqrt{ }$ & $\sqrt{ }$ & $\sqrt{ }$ & \\
\hline \multicolumn{3}{|c|}{ Number of sites for sightings } & 3 & 3 & 3 & 4 & 4 & 4 & 5 & 4 & 9 & 8 & 9 & 6 \\
\hline \multicolumn{3}{|c|}{ Total number of individuals } & 5 & 4 & 5 & 6 & 5 & 6 & 7 & 6 & 11 & 10 & 10 & 6 \\
\hline
\end{tabular}

Notes. Each tick mark represents sighting of dolphins in the particular location during corresponding visit and not the number of dolphin individuals sighted. The last row of the table, however, shows the total number of dolphins sighted in a particular visit (month column).

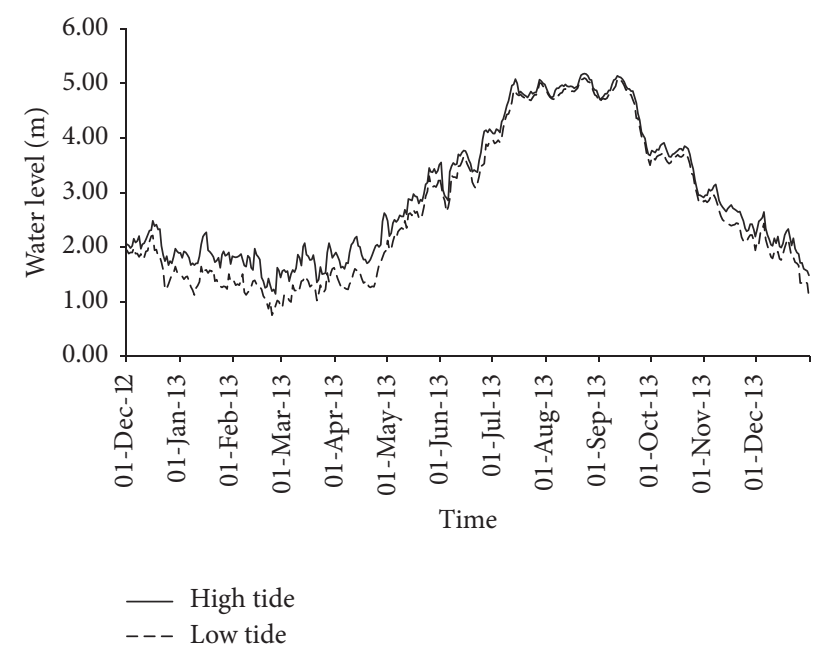

Figure 2: Water level on different time in the Turag River ecology.

with "yes" from 15 boatmen and 12 fishermen through crosscheck interview in the bank of the river.

We recorded maximum encounter rate of 0.49 sightings $\mathrm{km}^{-1}$ in October 2013 in the Turag River (Figure 6). On the other hand, encounter rate was 0.13 in the Jamuna River $(189.6 \mathrm{~km})$ in October 1995 and 0.08 sightings $\mathrm{km}^{-1}$ in the Kushiyara River $(113.0 \mathrm{~km})$ in April 1996 [33]. The encounter rate in the Brahmaputra River was 0.24 sightings $\mathrm{km}^{-1}$ [34] and in the Karnaphuli river it was 0.76 sightings $\mathrm{km}^{-1}$, respectively [22]. In a survey in the Koshi River, Nepal (a range of $38 \mathrm{~km}$ ), also eight dolphins sightings were recorded between the Koshi Barrage and Barahachetra during the period from October 2006 to January 2007 [35]. The variations in encounter rates of this river dolphin might be attributed to length and width of the rivers. The water level and dolphin density $(r=0.80)$ or the water level and sightings presented a strong positive correlation $(r=0.73)$, meaning that more dolphins can be sighted in high water level. Water level could be an important factor that influenced

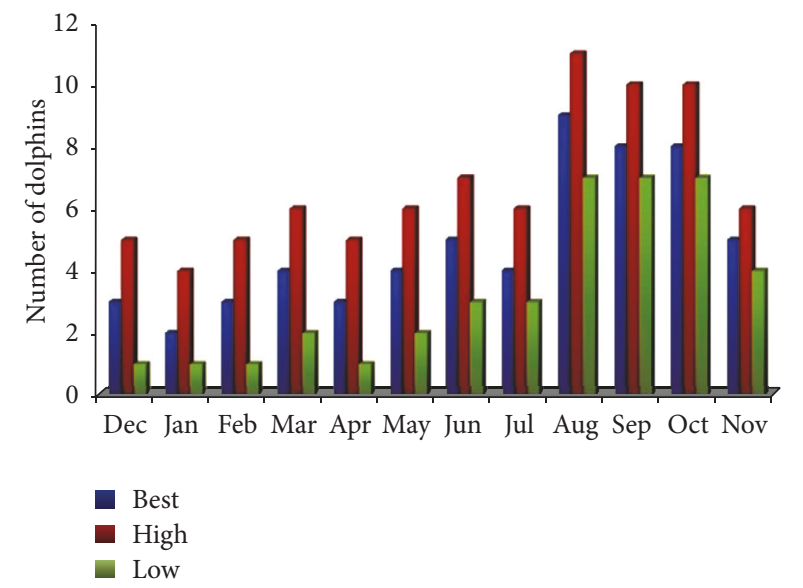

FIgURE 3: Best-high-low estimate of river dolphins in the Turag River.

the dolphin density and sighting in this study area. The changes in dolphin's densities are due to fluctuations in water levels [20]. Ganges river dolphins also appeared in various rivers of the Sub-Himalayan Cooch Behar district of West Bengal, India, on dry season habitat condition [2]. Therefore, in the dry season, dolphins may leave Turag mainly due to adverse water quality of this river and again return to Turag in the time of high water level (during rainy season).

The results of this study can lend insight into a number of ecological features driving the formation of groups in river dolphins and direct the focus of further research and influence management actions. Chemical pollution, in addition to habitat destruction, is a significant factor in the observed decreases in river dolphin populations [36]. Furthermore, river dolphins are often found in small groups, with two individuals being the most common group size found in this study (Table 1). The Ganges river dolphin usually travels alone or in small groups, but as many as 3 to 10 individuals have also been observed feeding in some other areas $[14,33]$. Further detailed studies are necessary 


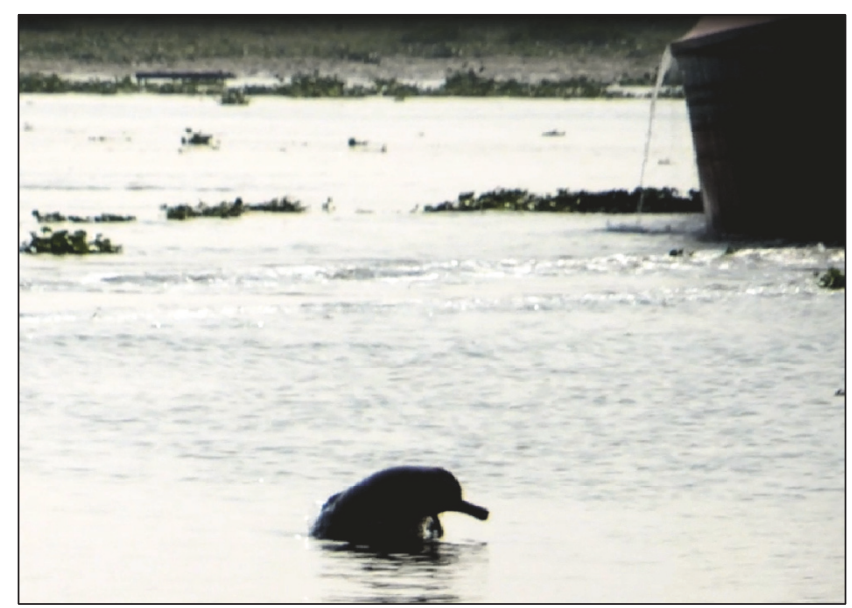

FIGURE 4: Transport vessels moved on feeding zone of river dolphin in the Turag River.
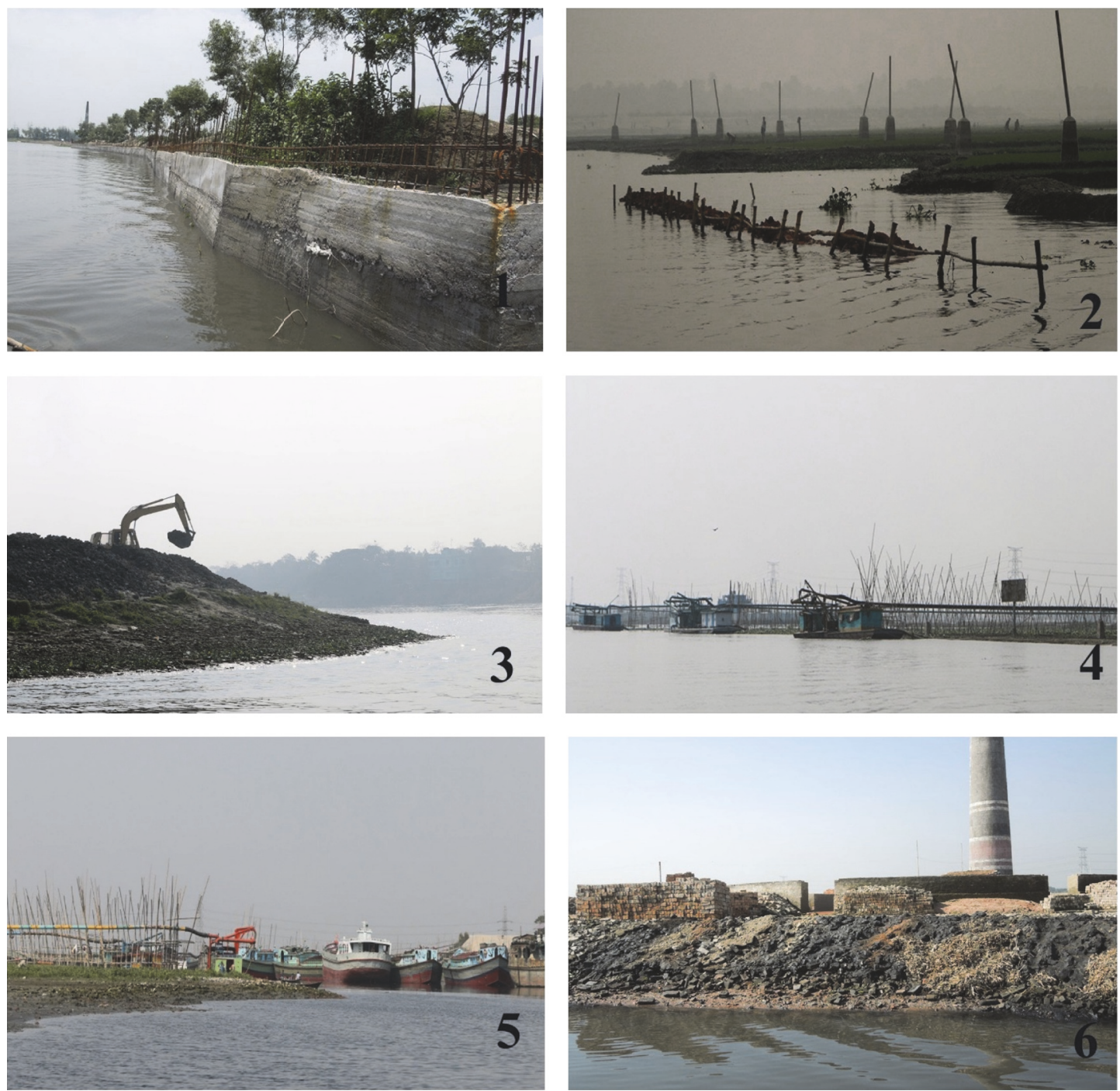

Figure 5: Environmental threats of Turag River. (1,2, and 3) Encroachment of river by filling up river beds. (4) River fill-up by sand using unload dredgers. (5) River blocked by water vessels. (6) Brick field along the river. 


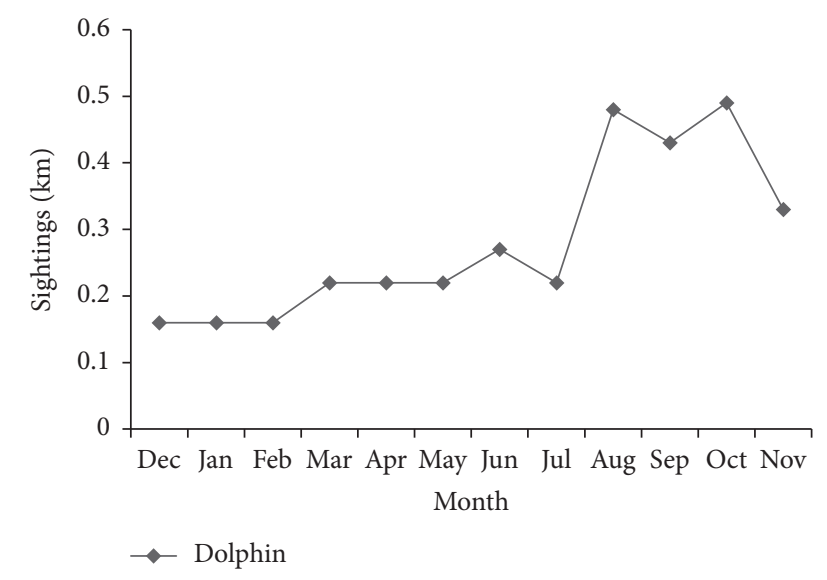

FIGURE 6: Monthly encounter rates of Ganges river dolphins in the Turag River.

to identify the causative/limiting factors. However, if this environment exists for long time, there is a possibility that the dolphin would face extirpation from this river.

Other threats to the Ganges river dolphin in the Turag River include boat traffic from motor vessels of different types and size $[11,12,26]$. Alam [37] found that, on average, 188 vehicles crossed two different observation points in the Buriganga River and another 1,270 vehicles remained standing around the same points. The constant noise of vessel traffic might inhibit the ability of river dolphins to avoid collision with potential fatal consequences [33]. However, we have frequently seen the dolphins to avoid vessels in the Turag River (Figure 4). Flood pulses are essential for maintaining productivity and seem to be major factors governing the dolphins' behavior. Furthermore, the entire river faces environmental threats by encroachment of river area for physical infrastructures like land and housing development, brick kilns, and sand loading, which make the river and river channel narrower, decreasing the dolphin habitat (Figure 5). Our results may provide some guidance for identifying areas of high conservation importance in the river ecology for river dolphins. Future research should focus on how river ecology is affected through flood or pollution for better management of natural resources and river dolphin. Also fund or support is required to conserve river dolphin in the Turag River.

The Ganges river dolphin is the only aquatic mammal in certain riverine ecosystems on the Indian subcontinent. It is one of four species of freshwater dolphins found globally. Various anthropogenic activities including industrial and domestic pollution, boat traffic, reduced water flow and prey depletion mainly in the dry season, and housing/land development projects along the Turag River are potential threats for the long-term survival of the Ganges river dolphin. Our study shows the need for improved public policies aiming at the conservation of this endangered dolphin species and for programs of environmental education to raise the awareness of local residents regarding their land and its fishes and dolphin. A wide study is straightway essential in the Turag River system for conservation of the species as it is endangered (A2abcde) in IUCN Red List. River dolphins need to be considered in the valuation of impacts of river water improvement plans.

\section{Conflicts of Interest}

The authors declare that they have no conflicts of interest.

\section{Acknowledgments}

This research was supported by Jagannath University Research Grants for 2012-2013 and Special Research Grant of the Ministry of Science and Technology, Government of Bangladesh, for 2012-2013. The authors would like to thank all the researchers of Biodiversity Conservation and Fisheries Research Center (BCFRC) who gave their support during the field survey and research.

\section{References}

[1] T. Bashir, A. Khan, P. Gautam, and S. K. Behera, "Abundance and prey availability assessment of ganges River dolphin (Platanista gangetica gangetica) in a stretch of upper Ganges River, India," Aquatic Mammals, vol. 36, no. 1, pp. 19-26, 2010.

[2] T. Kasuya and A. K. M. Haque, "Aminul, Some information on distribution and seasonal movement of Ganges dolphin," The Scientific Reports of the Whales Institute, vol. 24, pp. 109-115, 1972.

[3] R. R. Reeves and S. Leatherwood, Report of the First Meeting of the Asian River Dolphin Committee, Ocean Park Conservation Foundation, Ocean Park, Hong Kong, 1995.

[4] B. D. Smith, G. T. Braulik, and R. Sinha, Platanista gangetica ssp. Gangetica, The IUCN Red List of Threatened Species, 2012, http://www.iucnredlist.org.

[5] S. Paudel, Y. P. Timilsina, J. Lewis, T. Ingersoll, and S. R. Jnawali, "Population status and habitat occupancy of endangered river dolphins in the Karnali River system of Nepal during low water season," Marine Mammal Science, vol. 31, no. 2, pp. 707-719, 2014.

[6] M. Klinowska, Dolphins, Porpoises and Whales of the World, vol. 61, The IUCN Red Data Book. IUCN, Gland, Switzerland and Cambridge, UK, 1991.

[7] R. K. Sinha and K. Kannan, "Ganges River Dolphin: An Overview of Biology, Ecology, and Conservation Status in India," AMBIO, vol. 43, no. 8, pp. 1029-1046, 2014.

[8] IUCN Bangladesh, "Red Book of Threatened Mammals of Bangladesh," IUCN- The World Conservation Union. xii +71 pp. 2000.

[9] D. Dudgeon, A. H. Arthington, M. O. Gessner et al., "Freshwater biodiversity: importance, threats, status and conservation challenges," Biological Reviews of the Cambridge Philosophical Society, vol. 81, no. 2, pp. 163-182, 2006.

[10] K. Alam, Cleaning up of the Buriganga River, Integrating the Environment into decision making [Ph.D. thesis], Murdoch University, Perth, Australia, 2003.

[11] Z. Banu, M. S. A. Chowdhury, K. Hossain, M. D. Hossain, and K. Nakagami, "Contamination and Ecological Risk Assessment of Heavy Metal in the Sediment of Turag River, Bangladesh: An Index Analysis Approach," Journal of Water Resource and Protection, vol. 5, pp. 239-248, 2013. 
[12] M. Khondker and S. G. Abed, "Seasonality of phytoplankton productivity of the river turag of Dhaka in relation to its water quality," Bangladesh Journal of Botany, vol. 42, no. 2, pp. 287294, 2013.

[13] A. U. Choudhury, Checklist of the Mammals of Assam, Gibbons Books, Guwahati, India, 1997.

[14] B. D. Smith, "1990 Status and conservation of the Ganges River dolphin Platanista gangetica in the Karnali River, Nepal," Biological Conservation, vol. 66, no. 3, pp. 159-169, 1993.

[15] B. Smith, R. Sinha, U. Regmi, and K. Sapkota, "Status of Ganges river dolphins (Platanista gangetica) in the Karnali, Mahakali, Narayani and Sapta Kosi rivers of Nepal and India in 1993," Marine Mammal Science, vol. 10, no. 3, pp. 368-375, 1994.

[16] R. K. Sinha, B. D. Smith, Sharma. et al., "Status and distribution of the Ganges susu. Platanista Gangetica, in the Ganges river system of India and Nepal," in Biology and Conservation of Freshwater Cetaceans in Asia, R. R. Reeves, B. D. Smith, and T. Kasuya, Eds., vol. 23, pp. 54-61, Occasional Papers of the IUCN Species Survival Commission, 2000.

[17] J. Anderson, Anatomical and zoological researches : comprising an account of the zoological results of the two expeditions to western Yunnan in 1868 and 1875; and a monograph of the two cetacean genera, Platanista and Orcella, vol. 2, B. Quaritch, London, UK, 1878.

[18] S. Jones, "The present status of the Gangetic Susu, Platanista gangetica (Roxburghii), with comments on the Indus Suru, P. minor (Owen)," FAO Advisory Committee on Marine Resources Research. Working party on marine mammals, vol. 5, no. 4, pp. 97-115, 1982.

[19] B. Ahmed, "Water development and the status of the shushuk (Platanista Gangetica) in Southeast Bangladesh," in Biology and Conservation of Freshwater Cetaceans in Asia, Occasional Papers of the IUCN Species Survival Commission, R. R. Reeves, B. D. Smith, and T. Kasuya, Eds., vol. No. 23, pp. 62-66, IUCN, Gland, Switzerland, 2000.

[20] R. R. Reeves and R. L. Brownell Jr., "Susu Platanista gangetica (Roxburgh, 1801) and Platanista minor (Owen, 1853)," in Handbook of Marine Mammals, S. H. Ridgway and R. Harrison, Eds., vol. 4, pp. 69-99, Academic Press, London, UK, 1989.

[21] in A Future for Asian River Dolphins: Report from the Seminar on the Conservation of River Dolphins of the Indian Subcontinent, R. R. Reeves, S. Leatherwood, and R. S. L. Mohan, Eds., Whale and Dolphin Conservation Society, New Delhi, India, August 1992.

[22] B. D. Smith, B. Ahmed, M. E. Ali, and G. Braulik, "Status of the Ganges river dolphin or shushuk Platanista gangetica in Kaptai Lake and the southern rivers of Bangladesh," ORYX, vol. 35, no. 1, pp. 61-72, 2001.

[23] DoE, The General over View of Pollution Status of River of Bangladesh, Government of the People's Republic of Bangladesh, Ministry of Environment and Forest, Department of Environment, Dhaka, Bangladesh, 2001.

[24] M. N. Mobin, M. S. Islam, M. Y. Mia, and B. Bakali, "Analysis of Physicochemical Properties of the Turag River Water, Tongi, Gazipur in Bangladesh," Journal of Environmental Science and Natural Resources, vol. 7, no. 1, pp. 27-33, 2014.

[25] S. M. Alam, M. M. Hossain, M. A. Baki, and N. A. Bhouiyan, "Status of ganges dolphin, Platanista gangetica gangetica (Roxburgh, 1801) in the river Buriganga, Dhaka," Bangladesh Journal of Zoology, vol. 43, no. 1, p. 109, 2015.

[26] S. M. I. Alam and N. Sarker, "Status and distribution of the gangetic dolphin, platanista gangetica gangetica (roxburgh,
1801) in river Buriganga During 2003-2004 and its conservation," Bangladesh Journal of Zoology, vol. 40, no. 1, pp. 21-31, 2012.

[27] S. Chaudhary, Status of, and Threats to, the Ganges River Dolphin (Platanista gangetica) in the Koshi River, Nepal [M.S. thesis], Department of Economics, University of Klagenfurt, Klagenfurt, Austria, 2007.

[28] N. I. Richman, J. M. Gibbons, S. T. Turvey et al., “To see or not to see: Investigating detectability of ganges river dolphins using a combined visual-acoustic survey," PLOS ONE, vol. 9, no. 5, Article ID e96811, 2014.

[29] T. K. Shrestha, "Biology, status and conservation of the Ganges river dolphin, Platanista gangetica, in Nepal," in Biology and Conservation of The River Dolphins, F. W. Perrin, R. L. Brownell Jr., Z. Kaiya, and L. Jiankang, Eds., vol. No. 3, pp. 70-76, Occasional papers of the IUCN Species Survival Commission, 1989.

[30] B. D. Smith and R. R. Reeves, "Survey methods for population assessment of asian river dolphins," in Biology and Conservation of Freshwater Cetaceans in Asia, R. R. Reeves, B. D. Smith, and T. Kasuya, Eds., vol. 23, pp. 97-115, Occasional Paper of the IUCN Species Survival Commission, 2000.

[31] M. M. Hossain, S. M. I. Alam, M. A. Baki, and N. A. Bhouiyan, "Ganges river dolphin," The Bulletin of the Ecological Society of America, vol. 97, no. 2, pp. 183-187, 2016.

[32] R. K. Sinha and G. Sharma, "Current status of the Ganges river dolphin in the rivers Koshi and Son," Journal of the Bombay Natural History Society, vol. 100, no. 1, pp. 27-37, 2003.

[33] B. Smith, H. A. Aminul, H. M. Shakhawat, and A. Khan, "River dolphins in Bangladesh: conservation and the effects of water development," Environmental Management, vol. 22, no. 3, pp. 323-335, 1998.

[34] A. Wakid and G. Braulik, Protection of endangered Gangetic dolphin in Brahmaputra River, Final report to IUCN-Sir Peter Scott Fund, Assam, India, 2009.

[35] T. K. Shrestha, "Biology, status and conservation of the Ganges river dolphin, Platanista gangetica, in Nepal," in Biology and Conservation of the River Dolphins. Occasional Papers of the IUCN Species Survival Commission, F. W. Perrin, R. L. Brownel Jr., Z. Kaiya, and L. Jiankang, Eds., vol. 3, pp. 70-76, IUCN, Gland, Switzerland, 1989.

[36] R. R. Reeves, "Rivers dolphins," in Encyclopedia of Marine Mammals, F. P. William, W. Bernd, and J. G. M. Thewissen, Eds., Academic Press, San Diego, Calif, USA, 2002.

[37] S. M. I. Alam, Status and distribution of the gangetic dolphin, Platanista gangetica gangetica (roxburgh, 1801) in river Buriganga During 2003-2004 and its conservation [M.S. thesis], The University of Dhaka, Dhaka, Bangladesh, 2005. 

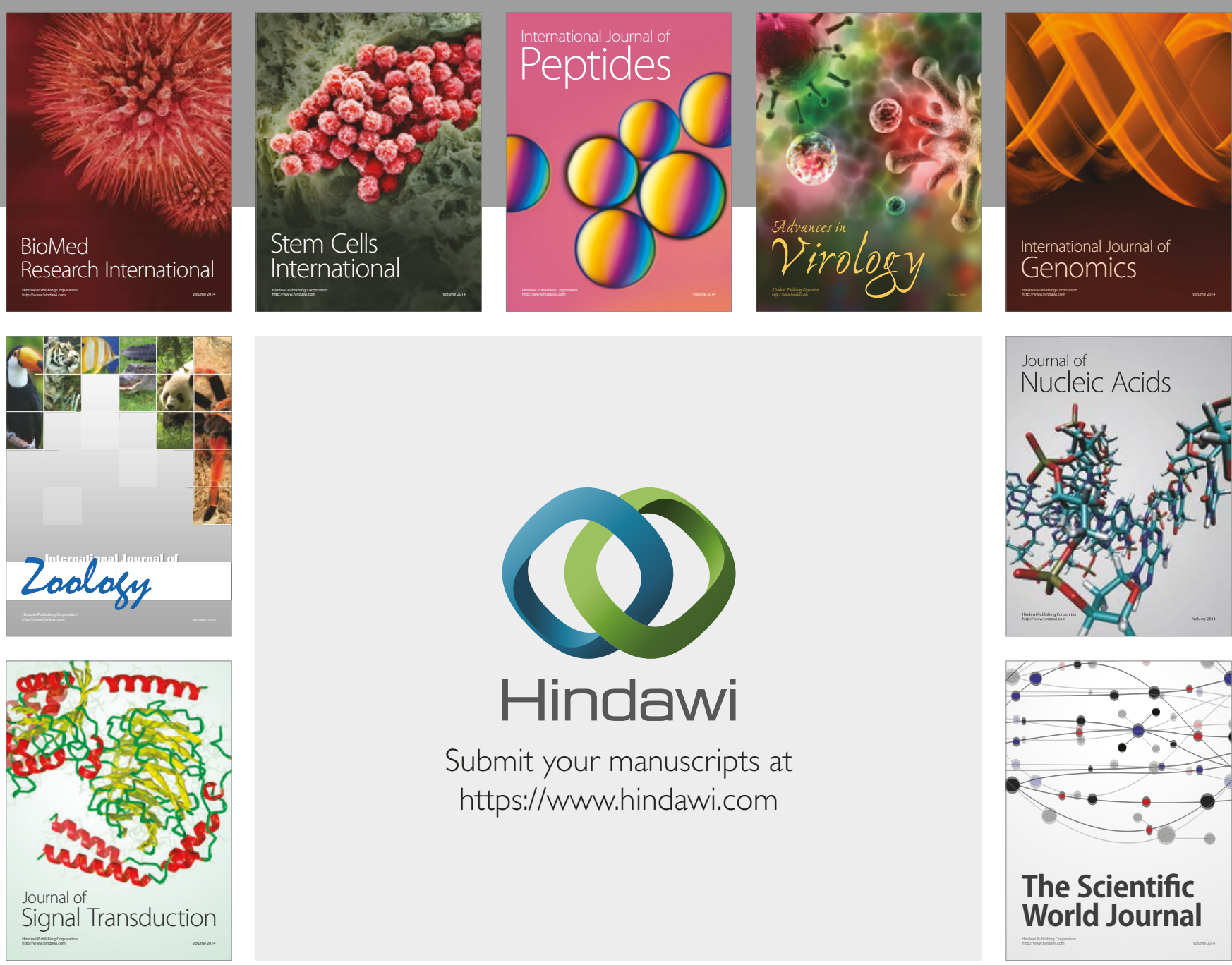

Submit your manuscripts at

https://www.hindawi.com
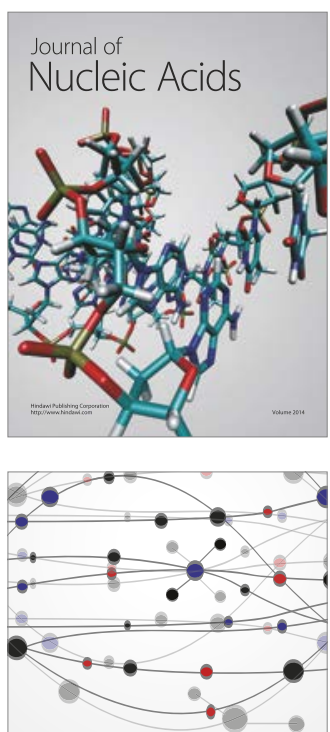

The Scientific World Journal

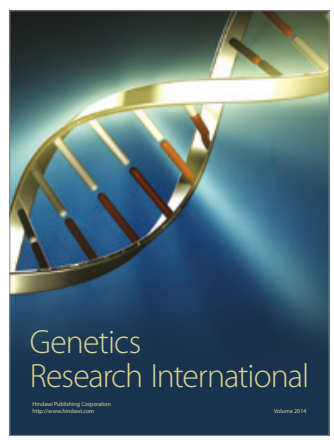

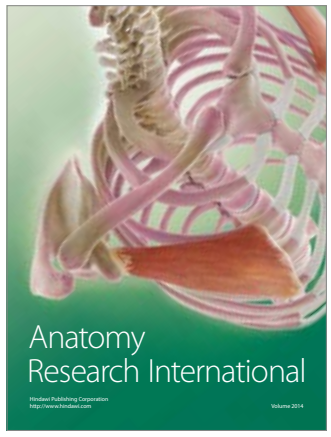

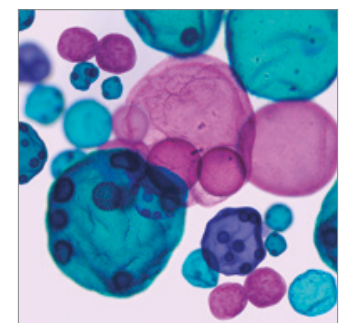

International Journal of Microbiology
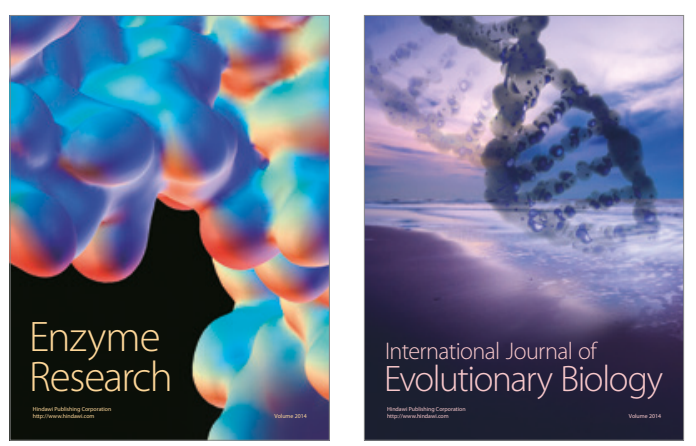
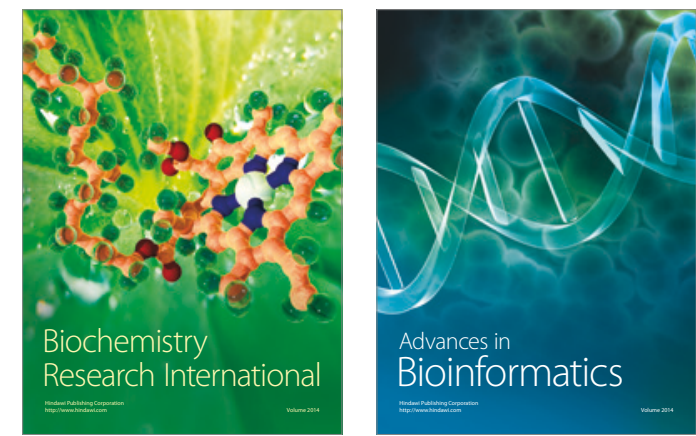

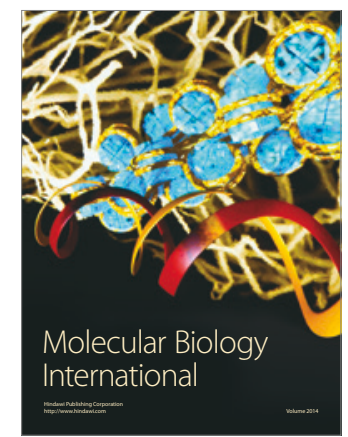

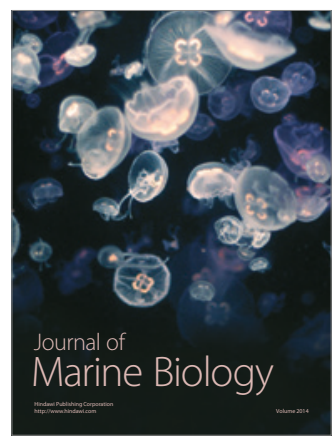

